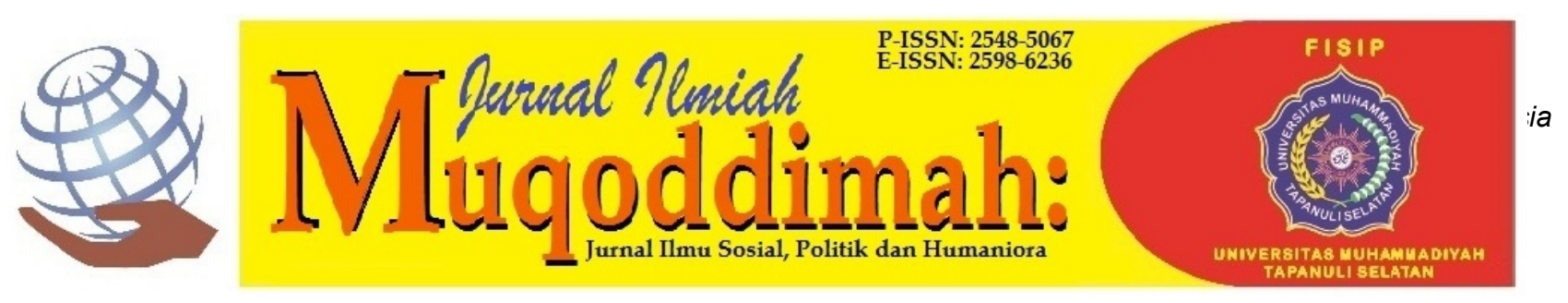

\title{
Dampak COVID-19 Pada Industri Siaran Televisi di Indonesia
}

\author{
Mustafa \\ Program Studi IImu Komunikasi Fakultas Dakwah dan Komunikasi UIN. Sultan Syarif Kasim Riau \\ Jalan HR. Soebrantas Panam Km. 15 Nomor 155, Kecamatan Tampan, Kota Pekanbaru, Indonesia \\ mustafa@uin-suska.ac.id
}

\begin{abstract}
Abstrak
COVID-19 membawa dampak bagi seluruh sektor kehidupan manusia termasuk media massa. Televisi menjadi favorit saat pemerintah mengeluarkan kebijakan berdiam di rumah dan pembatasan sosial berskala besar bagi warga di Indonesia. Menggunakan metode penelitian pustaka, penelitian ini ingin mengungkap apa dampak COVID-19 terhadap industri siaran televisi di Indonesia. Hasil penelitian menunjukkan ada beberapa perubahan yang terjadi di industri televisi Indonesia yakni menghentikan syuting program sementara, re run, siaran langsung tanpa penonton, siaran dari rumah, penerapan protokol kesehatan di studio dan lapangan untuk keperluan kru, serta bekerja dengan kru yang minimalis. Media televisi di Indonesia perlu serius untuk bertahan dan berkompetisi di tengah-tengah situasi yang tidak menentu.
\end{abstract}

Kata kunci: Covid-19; Industri, Nasional, Televisi, Program, Siaran

\begin{abstract}
COVID-19 has an impact on all sectors of human life, including mass media. Television became a favorite when the government issued a policy of staying at home and large-scale social restrictions for citizens in Indonesia. Using library research methods, this study wants to reveal what impact COVID-19 has on the television broadcast industry in Indonesia. The results showed that there were some changes that occurred in the Indonesian television industry, namely stopping filming programs temporarily, re-running, live broadcast without spectators, broadcasts from home, applying health protocols in the studio and field for crew needs, as well as working with a minimalist crew. Television media in Indonesia need to be serious to survive and compete in the midst of uncertain situations.
\end{abstract}

Key words: Covid-19; Broadcast, National;Television Industry; Program,

\section{PENDAHULUAN}

Media memainkan peran penting selama masa awal COVID-19. Penelitian World Economic Forum menunjukkan, di masa pandemi COVID-19, antara 80 persen dan 90 persen orang mengkonsumsi berita dan hiburan selama rata-rata hampir 24 jam selama seminggu.(Hall, Stefan \& Li, Cathy, 2020). Televisi menjadi media yang paling banyak diminati warga saat kebijakan di tinggal rumah. TV menjadi sumber informasi terpercaya. Selera pemirsa telah meluas karena mereka memiliki lebih banyak waktu untuk menonton dan mencoba konten dan platform baru. (COVID-19 and TV, 2020)

Kebiasaan pemirsa TV selama masa pandemi ini juga telah berubah. Laporan terbaru Comcast menunjukkan perubahan yang paling jelas di samping jumlah jam yang dihabiskan menonton TV, adalah apa yang mereka tonton dan kapan waktu menonton. Pemirsa menonton lebih banyak berita meningkat selama minggu terakhir bulan Maret 
ketika jumlah kasus Covid-19 global mencapai 1 juta. Secara umum minat dalam menonton ada pada drama sebesar 30 persen, diikuti oleh berita 29 persen, komedi 28 persen, reality show 15 persen dan aksi dan petualangan 15 persen.(Butts, Tom, 2020)

Indonesia adalah negara yang ikut terjangkit kasus COVID-19 sejak awal Maret 2020 (Ihsanuddin, 2020). Pemerintah kemudian mengimbau masyarakat untuk bekerja dan beribadah dari rumah (CNN Indonesia, 2020). Kebijakan ini tentu saja berdampak banyaknya orang yang berdiam di rumah dan menghabiskan waktu untuk menonton televisi.

Hasil pemantauan Nielsen Television Audience Measurement (TAM) di 11 kota di Indonesia menunjukkan jumlah kepemirsaan TV pada bulan Maret 2020 mulai meningkat dari rata-rata rating 12 persen di tanggal 11 Maret menjadi 13,8 persen di tanggal 18 Maret atau setara dengan penambahan sekitar 1 juta pemirsa TV.(Lubis, Mila, 2020) Rata-rata waktu menonton TV masyarakat Indonesia di pekan terakhir bulan lalu Maret 2020 ada di angka 3 jam 29 menit. Rerata ini lebih kecil dibanding peningkatan waktu menonton TV warga negara lain. Dalam riset yang sama terlihat, Malaysia mengalami kenaikan hingga 5 jam 7 menit pada pekan terakhir Maret. Kenaikan ratarata yang lebih tinggi juga terjadi di Afrika Selatan (4 jam 01 menit), Mexico (4 jam 8 menit), Italia (6 jam 10 menit) Yunani (7 jam 19 menit), dan Serbia (7 jam 45 menit).(Hidayatullah, 2020)

Selama krisis kesehatan, masyarakat bergantung pada media untuk mendapat informasi yang akurat dan terbaru untuk membuat keputusan yang tepat mengenai perilaku perlindungan kesehatan. Selama masa ketidakpastian dan krisis, ketergantungan mereka pada media juga dapat meningkat.(Ball-Rokeach \& DeFleur, 1976). Di Indonesia masyarakat percaya bahwa media konvensional seperti televisi tidak akan menyebarkan berita palsu, karena itu terkait isu COVID-19 warga mencari konfirmasi kebenaran di televisi, koran atau situs online yang terpercaya.(Luhur, Puthut Ami, 2020)

Televisi menjadi satu di antara sekian banyak industri hiburan yang memberikan kesenangan (pleasure). Kekuatan televisi terletak pada kemampuannya membuat orang mencari informasi, pengetahuan dan hiburan. Pemilihan program sebenarnya menjadi respons media televisi atas ritme budaya masyarakat. Secara umum televisi memiliki pemirsa yang beragam di tengah masyarakat. Konsekuensinya televisi berorientasi meraih keuntungan dan membutuhkan modal yang besar. Oleh karena itu televisi senantiasa membaurkan diri ke dalam kegiatan industri. (Mustika, 2016)

Industri televisi, pada akhir abad ke-20, telah tumbuh menjadi kekuatan ekonomi yang menghasilkan pendapatan, biaya, laba, dan dampak media massa yang paling besar. (Gomery, 2001) Stasiun televisi dapat memprogram 24 jam sehari, dalam hal tertentu ada kendala pada penawaran program yang dapat mereka tawarkan pada waktu tertentu. Stasiun TV dan radio hanya dapat memprogram waktu komersial (iklan) beberapa jam; jika tidak, pemirsa dan pendengar dapat berpaling. Fitur unik dari industri media adalah bahwa produk mereka dapat digunakan kembali berulang kali. Program TV, musik, dan film dapat didaur ulang berkali-kali, tidak seperti barel minyak atau komoditas lain, yang dikonsumsi habis (Albarran, Alan. B, 2010).

Industri media dapat memperluas kekuatan itu dengan membuat konten yang menghasilkan pendapatan setiap kali digunakan dan digunakan kembali oleh audiens di 
seluruh dunia. Perusahaan kemudian memperdalam aliran pendapatan ketika mereka mengambil konten yang sama dan mengemasnya kembali untuk digunakan dan digunakan kembali oleh anak perusahaan yang menjangkau seluruh sektor media cetak, video, film, dan media baru.(Mosco, 2009).

Ketika masa pandemi, dunia penyiaran khususnya televisi berubah dari hanya sekedar media yang memberikan informasi menjadi pemantik gerakan sosial. Pandemi HIV dan AIDS muncul di Afrika Selatan selama 1980-an, adalah salah satu contohnya. Broadcasting the Pandemic adalah sejarah televisi kontemporer di Afrika Selatan, dan perannya dalam gerakan sosial paling berpengaruh yang muncul dari transisi demokrasi: gerakan aktivis HIV. Gerakan ini dibentuk oleh sejumlah organisasi masyarakat sipil, termasuk kelompok advokasi kesehatan dan hukum, kelompok perempuan, serikat pekerja dan organisasi gereja. Pemimpin organisasi gerakan, bagaimanapun, adalah Kampanye Aksi Perawatan (TAC). Selama waktu siarannya, Beat It! memantapkan dirinya sebagai sayap media televisi dari gerakan aktivis HIV, menggunakan media siaran untuk memobilisasi dukungan untuk advokasi dan untuk mempopulerkan tuntutannya. Dengan menampilkan bentuk-bentuk identitas sosial, subjektivitas politik, dan keterlibatan aktivis yang muncul dengan negara di era pasca-apartheid, Beat It! menggabungkan dorongan mendemokratisasi ganda dari media televisi dan gerakan sosial baru. Pada akhirnya, acara ini dibuat bukan sebagai reaksi terhadap kebijakan HIV pejabat tinggi negara, tetapi sebagai tanggapan terhadap pengalaman mengerikan dari anggota komunitas HIV-positif.(Hodes, 2014)

Pada tahun 2020, tayangan ulang berlangsung sebagai tulang punggung televisi. (Johnson, 2020) Seperti dilaporkan Variety, banyak outlet televisi "memperluas wawasan mereka" dengan memperoleh hak atas konten yang sebelumnya telah ditayangkan di tempat lain untuk mengisi celah dalam program mereka. Dalam merangkul nilai-nilai alternatif pengulangan, layanan televisi ini hanya memanfaatkan logika yang selalu membentuk industri televisi dan budaya televisi, bahkan jika kadang-kadang diabaikan demi kemewahan, baru, dan eksklusif.(Low, Elaine \& Otterson, Joe, 2020)

Amanda D Lotz menilai konglomerasi media juga telah lama mendukung praktik "realokasi" di mana seri yang dikembangkan untuk satu jaringan atau saluran dapat digunakan kembali di jaringan lain di bawah panji perusahaan yang sama.(Lotz, Amanda D., 2007) Fokus pada pemrograman asli juga mengaburkan banyak pengalaman aktual menonton televisi linear dan non-linear. Jaringan siaran tradisional dan saluran kabel mengedepankan pemrograman primetime asli, pada sebagian besar jam pemirsa lebih mungkin menemukan tayangan ulang seri lama dan film yang sama yang telah diputar berulang selama berminggu-minggu.

Pandemi virus corona telah memaksa stasiun televisi di beberapa negara untuk menunda pembuatan acara film populer, merekam program format live-audience di studio kosong, dan menjalankan replay acara olahraga. Tetapi sementara media penyiaran dunia merespons dengan memikirkan kembali jadwal pemrograman dan mengambil langkah-langkah untuk melindungi presenter, kru produksi, dan pekerja lain, beberapa organisasi melangkah lebih jauh - menyediakan konten yang dirancang untuk membantu pemirsa dan pendengar mengatasi krisis. Pada tanggal 18 Maret 2020, ketika Inggris meningkatkan langkah-langkah untuk mengurangi penyebaran virus, British Broadcasting Corporation (BBC) menetapkan bagaimana mereka akan menegakkan 
prinsip-prinsipnya untuk menjaga bangsa "terinformasi, terdidik, dan teribur di masa yang belum pernah terjadi sebelumnya".(Hutt, Rosamond, 2020)

Rencana tersebut meliputi penyiaran acara TV prime-time mingguan di COVID-19, memproduksi podcast COVID-19 setiap hari, dan menjawab pertanyaan pendengar dengan telepon biasa melalui layanan radio nasional BBC 5 Live. Stasiun radio BBC lokal akan membantu masyarakat dengan bekerja sama dengan kelompok sukarelawan untuk mendukung lansia dan orang-orang rentan lainnya. Antara pukul 6 pagi dan tengah hari, keluaran mereka akan fokus pada berita coronavirus, telepon masuk, dan saran ahli. Dalam upaya untuk membantu orang "mengatasi dampak krisis pada kehidupan mereka sendiri." BBC merencanakan program yang bertujuan memberikan kenyamanan kepada orang-orang yang terisolasi dan membantu mereka tetap bugar dan makan sehat. Akan ada layanan gereja virtual pada hari Minggu pagi di radio lokal BBC juga akan bertujuan untuk menyiarkan layanan Minggu mingguan televisi dan melihat bagaimana mendukung agama dan denominasi lain.(Hutt, Rosamond, 2020)

Di Senegal muncul sebuah TV Show dijuluki The Virus, ditayangkan di media sosial dan di saluran pribadi, berfokus pada kehidupan selama pandemi. Bintang drama TV terbaru Senegal adalah seorang dokter fiksi yang memberikan saran coronavirus jauh dari karakter dalam sinetron bertema perselingkuhan yang biasa dilakukan negara Afrika Barat itu. (AFP News Agency, 2020) Di China, Korea Selatan dan Italia, layanan industri TV dan video cenderung mengalami peningkatan jumlah pemirsa. Namun, media yang didanai iklan sangat terpukul oleh penurunan kegiatan ekonomi. Media yang didanai berlangganan tidak mungkin terkena dampak buruk dan bahkan mungkin mendapat manfaat karena orang-orang yang terpaksa tinggal di rumah karena sakit atau terisolasi akan memiliki lebih banyak waktu daripada jika mereka bepergian ke tempat kerja.(Wesscott, Tim, 2020)

Lembaga Penyiaran Publik Italia, Rai TV, telah meningkatkan output program anak-anak, menambahkan slot anak-anak baru ke saluran Rai 2 dan pada layanan online Rai Play dan Rai Play Yoyo. Secara lebih luas, pembatasan perjalanan dan ukuran pertemuan menyebabkan gangguan luas terhadap industri TV. Lembaga Penyiaran AS, CBS, menangguhkan produksi seri realitasnya The Amazing Race sementara di Inggris opera sabun ITV Coronation Street akan membutuhkan penulisan ulang setelah anggota pemeran diisolasi sendiri. Asosiasi produsen Inggris PACT, mengungkapkan bahwa produsen telah menemui kesulitan dalam mendapatkan perlindungan asuransi untuk produksinya.(Wesscott, Tim, 2020)

Banyak host televisi paling populer dan berpengaruh di Amerika sekarang menyiarkan langsung dari kamar tidur dan ruang bawah tanah. Beberapa siaran berita TV, majalah, dan situs web diproduksi sepenuhnya dari jarak jauh, dengan pengaturan yang tidak terpikirkan sebelumnya. Perusahaan media mengikuti pedoman jarak sosial yang sama dengan industri lainnya. Beberapa penyiar mengkarantina diri karena mereka berada dekat dengan orang yang dites positif terkena virus. Ada yang hilang yakni studio multi-juta dolar dan kualitas video yang menyertainya dan ada yang baru yakni efisiensi dan keintiman.(Business, 2020)

Di Spanyol rutinitas kerja tim produksi televisi sangat terpengaruh oleh wabah COVID-19. Ini berarti adaptasi terhadap lingkungan teknologi baru yang pada gilirannya berdampak pada hasil akhir oleh direktur dan semua tim yang bekerja sama dalam 
praproduksi program. Juga terjadi peningkatan sinyal yang datang dari Skype, Zoom, panggilan video seluler, dan lain-lain telah menyebabkan penurunan kualitas ketika sampai pada produk audio-visual akhir. (Andueza-López \& López-Plaza, 2020)

Penelitian ini ingin melihat bagaimana dampak COVID-19 terhadap industri siaran televisi di Indonesia khususnya televisi teresterial nasional. Apa saja aspek yang berubah dan bagaimana perubahan itu terjadi.

\section{METODE}

Artikel ini menggunakan metode library research. Diawali dengan cara mengidentifikasi dan menemukan informasi yang relevan (Culinary, 2020), menganalisis apa yang ditemukan, dan kemudian mengembangkan dan mengekspresikan ide-ide yang ditemukan. Sumber utama dalam penelitian ini adalah berita online, dan konten diskusi youtube yang memuat topik yang sedang dibahas yang digelar oleh Ikatan Jurnalis Televisi Indonesia dan MarkPlus.

Sedangkan, sumber sekunder adalah hasil kajian oleh peneliti lain yang menggambarkan, menganalisis, dan/atau mengevaluasi informasi yang relevan dengan penelitian. Kemudian, informasi temuan tersebut dikemas ulang sehingga sumber sekunder membuat informasi lebih mudah diakses. Beberapa contoh sumber sekunder adalah buku, jurnal dan artikel majalah, ensiklopedi, review dan lain-lain(UAF, 2018).

Mengingat keterbatasan, studi ini hanya akan mencoba untuk menelaah dampak pandemi COVID-19 terhadap televisi nasional teresterial yang berpusat di Jakarta antara lain MNC Group yang di dalamnya ada RCTI, MNC TV, dan Global TV, SCM yang menaungi SCTV dan Indosiar, TV One dan ANTV, Trans Media, dan TVRI sebagai lembaga penyiaran publik.selama tiga bulan awal kasus COVID-19 di Indonesia yakni dari bulan Maret sampai dengan Mei 2020 atau di masa awal penerapan Pembatasan Sosial Berskala Besar (PSBB).

\section{HASIL DAN PEMBAHASAN}

COVID 19 telah membawa dampak bagi industri siaran televisi di Indonesia. Secara umum dampak COVID-19 terhadap industri siaran televisi di Indonesia dapat dilihat pada tabel berikut:

Tabel 1

Dampak COVID-19 Terhadap Industri Siaran Televisi di Indonesia

\begin{tabular}{cll}
\hline No & \multicolumn{1}{c}{ Sebelum Covid } & \multicolumn{1}{c}{ Setelah Covid } \\
\hline 1 & Syuting Lancar & Berhenti Syuting \\
2 & Live dengan Penonton & Live Tanpa Penonton \\
3 & Konten baru & Re Run (Tayang Ulang) \\
4 & Siaran di Studio dan Lapangan & Siaran dari rumah \\
5 & Hiburan Anak & Belajar dari Rumah \\
6 & In House Production & TV Poll dan Kolaborasi \\
7 & Tanpa protokol kesehatan & Protokol kesehatan \\
\hline
\end{tabular}

Sumber: Hasil Penelitian, 2020 
Dalam rangka menanggulangi penyebaran COVID-19, Pemerintah melalui Menteri Kesehatan Terawan Agus Putranto telah mengelurkan Peraturan Menteri Kesehatan (PMK) Nomor 9 Tahun 2020 tentang Penetapan Pembatasan Sosial Bersakala Besar. Dalam peraturan ini juga Peliburan Tempat Kerja Pembatasan bekerja di tempat kerja diganti dengan bekerja di rumah/tempat tinggal. Dikecualikan bagi TNI Polri, kebutuhan pangan, BBM, pelayanan kesehatan, perekonomian, keuangan, komunikasi, industri, ekspor-impor, distribusi, logistik, dan kebutuhan dasar lainnya. Kecuali TNI Polri, kantor lain harus bekerja dengan jumlah minimum karyawan (BBC News, 2020)

Kementerian Komunikasi dan Informatika juga meminta stasiun televisi menghentikan sementara produksi program yang melibatkan banyak orang selama wabah virus corona (covid-19) berlangsung. Karena program baru yang akan melibatkan artis-artis atau tim teknis di lapangan yang bisa berbahaya atau mungkin bisa terjadi penyebaran virus di antara karyawan industri televisi. Menteri Komunikasi dan Informatika Johnny G Plate mengusulkan televisi menggunakan program yang lama untuk mengganti produksi yang terhenti sementara (Evandio, Akbar, 2020).

Imbauan ini juga didukung oleh Dewan Perwakilan Rakyat melalui Ketua Komisi I DPR Meutya Vidya Hafid. Dia meminta seluruh lembaga penyiaran publik dan swasta untuk mengatur ulang seluruh program tayangan yang melibatkan banyak audiens di antaranya program pencari bakat bidang musik, program talkshow, dan program hiburan yang melibatkan banyak penonton. Pihaknya ingin seluruh TV di Indonesia menjalankan himbauan pemerintah untuk menjaga jarak seperti pembatasan pengumpulan massa, 14 hari semenjak tanggal 16 Maret2020.(Media, 2020a).

Kementerian Pendidikan dan Kebudayaan (Kemdikbud) juga mengimbau stasiun televisi (TV) untuk menghentikan sementara kegiatan syuting. Imbauan itu disampaikan dalam Surat Imbauan Terkait COVID-19 bernomor 2944/F.F3/HM/2020. Surat bertanggal 24 Maret 2020 itu ditandatangani oleh Dirjen Kebudayaan Hilmar Farid.(Bisnis, 2020) Dua hari kemudian Polri mengeluarkan imbauan kepada production house $(\mathrm{PH})$ agar tidak melakukan kegiatan pengambilan film atau syuting guna membantu pencegahan penyebaran virus Corona atau Covid-19. Hal tersebut tertuang dalam surat bernomor B/483/III/HUM.5.3./2020/Divhumas tertanggal 26 Maret 2020.(Nugraha, Bayu \& Simbolon, Foe Peace, 2020)

Kondisi ini tentu saja membuat beberapa program yang sudah disusun oleh televisi di Indonesia harus berhenti sementara atau memutar otak untuk bertahan padahal stasiun televisi harus tetap menyuguhkan program acara kepada pemirsa yang sudah banyak di rumah.

\section{Berhenti Syuting}

Dampak yang dirasakan akibat dari pemberlakuan Pembatasan Sosial Berskala Besar (PSBB) adalah terhentinya syuting beberapa program sinetron yang dilakukan oleh production house yang selama ini menjadi supplier sinteron di televisi. Rumah produksi SinemArt menghentikan seluruh kegiatan syuting mulai 25 Maret 2020. Produser Leo Sutanto dalam pernyataan tertulisnya, mengatakan kebijakan ini diambil untuk mencegah penyebaran virus COVID-19. SinemArt memiliki beberapa judul sinetron yang sedang tayang di stasiun televisi swasta seperti Istri Kedua, Samudra 
Cinta, Kisah Cinta Anak Tiri, Anak Langit, dan Cinta Karena Cinta yang tayang di SCTV.(Media, 2020b)

RCTI juga menghentikan tayangan sinetron Sayap Ibuda karena berhenti syuting(Yuwono, Hanang, 2020). Stasiun ini juga menghentikan syuting Dunia Terbalik yang menjadi primadona tayangan tengah malam. Sinetron bawang putih di ANTV juga berhenti syuting. (Rahmat, 2020). Rumah produksi, Rapi Films juga menghentikan seluruh aktivitas produksi film. Bahkan kegiatan kantor pun dihentikan. "Prinsipnya benar-benar bubar, enggak ada yang bekerja," kata Sunil Samtani Direktur Eksekutif Rapi Films. Jika ada produksi sinetron atau film akan ada 100-120 orang dalam satu lokasi, dan akan sulit menjaga jarak untuk orang sebanyak itu..Oleh karena itu lebih baik kegiatan syuting dihentikan. Produser Eksekutif Starivision Plus, Chand Parwez Servia sepakat menunda aktivitas syuting. Starvision sudah menetapkan sejumlah SOP seperti sterilisasi, penyemprotan disinfektan, dan menjaga kebersihan. Tiap rumah produksi memiliki kebijakan masing-masing terhadap upah pekerjanya. Rapi Films misalnya, memberikan kebijakan upah semasa proyek ditunda. Starvision Plus juga melakukan kebijakan terkait upah yang menjadi fokus utamanya. Direktur Komunikasi Saiful Mujani Research and Consulting (SMRC) sekaligus pengamat film Ade Armando mengatakan kondisi pandemi Covid-19 ini bisa menjadi kesempatan insan kreatif menyiapkan konten-konten baru. Dia memprediksi setelah pertengahan tahun nanti bioskop menjadi pelarian hiburan publik.(developer, 2020)

CEO MNC David Fernando Audy dalam Industry Roundtable Episode ke 13 tentang Broadcast, Pay TV and Media Industry Perspective yang digelar Mark Plus juga mengakui masalah syuting yang tidak seperti sebelum wabah COVID-19. "Kami kesulitan syuting karena terhenti. Biasanya acara ramai-ramai Indonesian Idol, selama masa ini susah untuk syuting. Kita gak bisa bikin acara di studio yang penontonnya banyak." (MarkPlus, 2020) Pemimpin Redaksi Trans 7 dan CNN Indonesia, Titin Rosmasari dalam diskusi Merumuskan Pola Baru Jurnalisme TV di Era New Normal yang digelar Ikatan Jurnalis Televisi Indonesia mengakui bahwa wabah ini membuat pihaknya kesulitan untuk membuat konten baru. Sampai bulan Maret sebelum PSBB, pihaknya masih mengirim kru ke lapangan untuk melakukan aktivitas syuting dan wawancara. Namun saat itu banyak yang menolak karena alasan imbauan pemerintah untuk menjaga jarak dan membatasi kerumunan. Akibatnya banyak rencana syuting yang tidak bisa dilaksanakan. Padahal hampir semua konten di Trans Media adalah kegiatan outdoor. (IJTI, 2020)

\section{Siarang Langsung tanpa Penonton}

Sebelum wabah COVID-19 hampir semua tayangan langsung di televisi selain program berita, dihadiri oleh penonton di studio. Program itu antara lain ajang pencarian bakat dan program talkshow.(Putra, Adi, 2020). Namun karena wabah COVID-19 dan imbauan pemerintah untuk menjaga jarak fisik, beberapa stasiun televisi menggelar siaran langsung tanpa penonton di studio hingga waktu yang belum bisa dipastikan. Berikut beberapa program televisi yang meniadakan penonton dalam siaran langsungnya.

Liga Dangdut Indonesia (LIDA) 2020 salah satu program pencarian bakat yang biasanya dihadiri banyak penonton, bahkan banyak yang datang dari daerah sesuai 
asal kontestan yang berkompetisi. Namun sejak wabah COVID-19 di Indonesia Indosiar mengambil keputusan untuk meniadakan penonton di studio. Program tetap berjalan namun tanpa adanya para pendukung kontestan yang biasanya memeriahkan acara. (Kapanlagi.com, 2020).

Program andalan Trans TV, Pagi-Pagi Pasti Happy juga tayang tanpa penonton sejak 16 Maret 2020 (Warta Kota, 2020). Program Brownis juga meniadakan penonton untuk menghindari penyebaran virus. Dialoh Ruben Onsu dan Ivan Gunawan dengan penonton yang mengundang keriuhan tak lagi ada. Acara ulang tahun Betrand Peto anak angkat Ruben Onsu yang direncanakan pada program ini terpaksa digelar tanpa adanya penontong. Rumah Uya di Trans 7 juga tidak lagi menyertakan penonton dalam siarannya. "Mewaspadai penyebaran COVID-19, Rumah Uya akan LIVE tanpa penonton. Yuk bantu hambat penyebaran corona dengan menghindari keramaian dan \#DiRumahAja sambil nonton RUMAH UYA tayang Senin s/d Jum'at pukul 16.00 WIB @officialtrans7," tulis akun Instagram Rumah Uya. (Putra, Adi, 2020). Program Mata Najwa talkshow politik paling populer dan paling banyak ditonton menurut survey Cyrus Network (Bernie, 2020) yang menyapa pemirsa setiap Rabu malam di Trans 7 tidak dihadiri penonton pada acara live sejak 18 Maret 2020. Di Awal kebijakan itu, narasumber pun tidak dihadirkan di studio. Dialog presenter Najwa Shihab dengan para narasumber dilakukan melalui video conference. (Priastuti, Clarissa Fauzany, 2020).
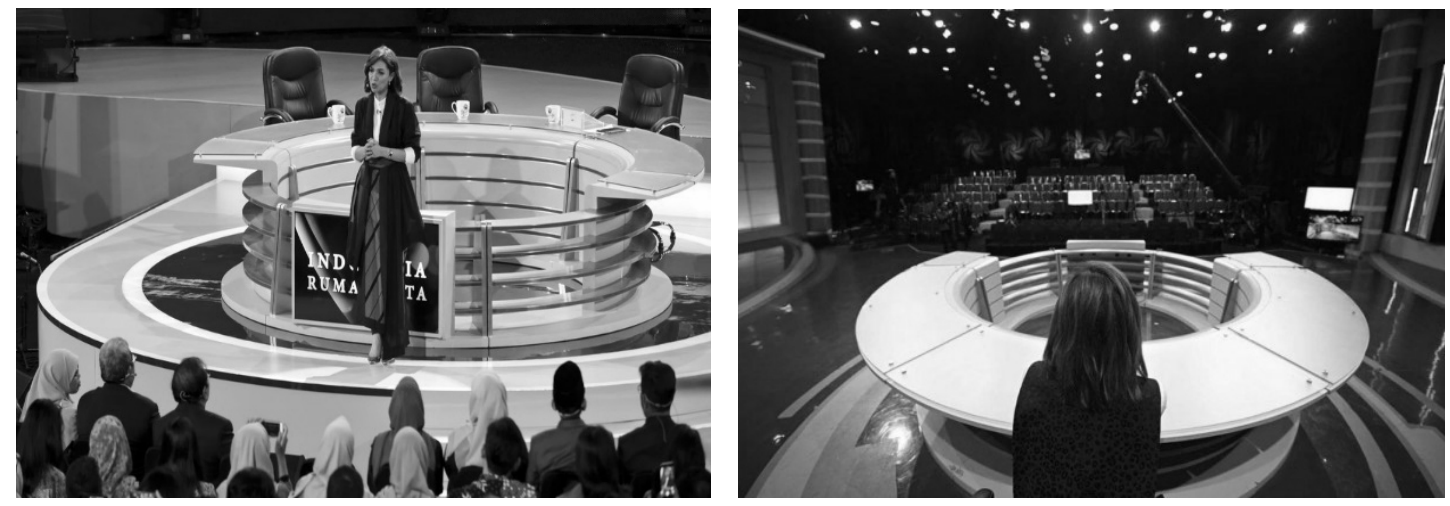

Gambar 1. (a) Program Mata Najwa sebelum COVID-19 syuting dipenuhi penonton (b) Program Mata Najwa sejak 18 Maret 2020 tayang tanpa penonton. (sumber (a) Tirto.id (b) IDNTimes.com)

Program Kick Andy yang dibawakan Andy F. Noya di Metro TV juga menggelar acara tanpa penonton. Kick Andy Heroes Award 2020 yang biasanya meriah setiap tahun akhirnya digelar tanpa adanya penonton (Zubaidah, Hanum, 2020). Hal yang sama juga dilakukan Indonesia Lawyers Club yang tayang di TV One setiap Selasa malam. Tayangan yang dipandu Karni llyas ini tayang tanpa penonton sejak 17 Maret 2020.(Sihite, Ezra, 2020). Overa van Java (OVJ) juga tayang live tanpa penonton. Dalam masa ini, setiap pemain OVJ yang diperiksa suhu tubuhnya oleh petugas, jika suhunya normal maka para pegawai dan artis diperbolehkan untuk melakukan kegiatan di studio. Para pemain OVJ sepakat jika ada salah satu pemain yang melakukan 
gimmick, mereka akan tertawa semua. Selain itu, penampilan di panggung yang seharusnya membuat penonton tertawa akan dimanipulasi dengan sound effect.(Gosip Artis, 2020)

Tidak hanya program yang berkala, program rutin tahunan seperti acara-acara sahur di bulan Ramadhan juga tampil dalam format yang berbeda dari biasanya yakni tanpa penonton. Tahun ini, Akademi Sahur Indonesia sangat berbeda dengan tahuntahun sebelumnya. Karena wabah pandemi, AKSI 2020 setiap peserta akan tampil melalui video dari rumah masing-masing lalu dinilai langsung oleh beberapa dewan juri dari studio. Ada 3 dewan juri yang akan terlibat dalam AKSI 2020, yakni Ustadz Subki Al Bughury, Ustadz Solmed, serta Ustadz Taufiqurrahman. Nama acara ini pun diubah dengan BerAKSI Di Rumah Saja.(Kapanlagi, 2020). Sahur Segerr yang tayang di Trans7 juga tidak dihadiri penonton. Acara televisi yang dibalut unsur komedi ini mengudara mulai Jumat, 24 April 2020 mulai pukul 2.00 WIB dengan dihiasi talk show, kuis interaktif, dan tausiah. Akan ada pula keterlibatan keluarga selebritas.(Pramudya, Windi Eka, 2020)

\section{Re Run (Tayang Ulang)}

Dampak pandemi COVID-19 akibat dari terbatasnya syuting di lapangan teutama pada program hiburan mengakibatkan beberapa stasiun televisi harus memutar otak untuk mengisi program acara. Kebanyakan televisi di Indonesia menayangkan ulang sinetron atau acara lama yang masih diminati penonton. RCTI misalnya, kembali menayangkan sinetron yang sudah lama. Dunia Terbalik, Anak Jalanan, 7 Manusia Harimau, dan Tukang Bubur Naik Haji. MNC Group memiliki sekitar 300 ribu jam konten sinetron maupun acara yang dapat ditayangkan ulang atau juga dijual ke media lain. Karena tidak mungkin membuat program baru. Hal ini dilakukan selain untuk tetap memberikan program yang berkualitas, juga untuk menekan biaya. Tayangan ulang tersebut masih mempunyai nilai jual di mata audiens. Artinya, meski sinetron yang ditayangkan adalah produksinya sudah lama sekali namun tetap mampu mendatangkan iklan. Strategi ini juga dilakukan televisi lain, termasuk SCTV, ANTV, dan Trans Media.

Sejak Maret-Juni 2020, ANTV telah menayangkan sedikitnya tiga sinetron lama, yakni Titipan Illahi, Muslimah dan Inayah. Adapun Trans Media kembali menayangkan Bajaj Bajuri, Kisah 9 Wali, dan Revolutionary Love. Adapun SCTV kembali menyajikan Ganteng-Ganteng Serigala, Samudera Cinta, dan Anak Langit. Corporate Secretary SCMA Gilang Iskandar menyebut, strategi rerun atau menayangkan ulang sinetron lama yang masih diminati adalah cara paling masuk akal untuk menyiasati kendala dalam produksi program baru. "Rerun adalah konsekuensi logis dari tidak bisa diproduksinya program yang baru. Kebanyakan yang non straight news di-rerun baik sinetron, FTV, dan lain-lain," terang Gilang melalui pesan singkat. (Rasdianto, Fajar Yusuf, 2020).

Cara melakukan tayang ulang ini juga disikapi berbeda oleh media televisi. Ada yang mengulang kembali tayangan secara utuh, ada juga yang menggabungkan beberapa adegan kompilasi dan mengemasnya ulang dalam episode special untuk mengisi kekosongan episode baru, seperti yang terjadi pada sinetron Dunia Terbalik. RCTI menayangkan ulang sinetron dari episode pertama, yang tayang pada 5 Januari 
2017 lalu untuk mengisi kekosongan episode karena berhenti syuting, sinetron ini diputar ulang dari episode awal.(Rahmat, 2020).

Presenter berita Trans7 Taufik Imansyah dalam Webinar Komunikasi yang digelar Program Studi IImu Komunikasi Universitas Jenderal Soedirman dengan tema Media Televisi Bertahan di Tengah Pandemi mengatakan di tempatnya bekerja yang direrun adalah program-program yang sudah terpilih. Yang memikiki kedekatan, rating cukup baik di awal penayangan, dan relevan dengan kondisi sekarang seperti Didi Kempot sudah syuting untuk Bukan Empat Mata. Lalu ditayangkan saat dia berpulang, ternyata mendapat respon positif dari penonton.(Komunikasi Unsoed, 2020).

Ada juga media televisi yang menayangkan judul kedua sebagai ganti sinetron yang tidak bisa tayang karena berhenti syuting. Judul kedua adalah tayangan yang awalnya tidak direncanakan khusus untuk Ramadhan, tapi tetap cocok untuk disiarkan. Yang paling penting, seluruh episodenya sudah rampung. Rumah produksi Sinemart misalnya menghentikan semua produksi, termasuk untuk bulan Ramadhan, tapi mereka punya judul lain yang ceritanya cocok untuk konten Ramadhan. "Untuk Ramadhan kami tidak bisa syuting, tapi ada judul-judul yang sebenarnya cocok untuk di Ramadhan, seperti yang dimainkan Cut Meyriska dan Roger Danuarta," kata humas Sinemart Dini Suryani. Meskipun begitu, keputusan akhir ada pada tim pemrograman televisi. (Kurniasih, Anisa, 2020)

\section{Siaran dari Rumah}

Jika sebelum masa COVID-19 di Indonesia maka syuting atau produksi siaran berlangsung normal bisa di studio atau di lapangan, pada masa COVID-19 agar tetap punya program yang menghibur dan baru, beberapa staisun televisi melakukan program siaran dari rumah. Dalam hal berita presenter melakukan siaran dari rumah atau melakukan wawancara jarak jauh dengan narasumber melalui video conference.

Retno Pinasti, Deputy In Chief PT Surya Citra Media yang menangani SCTV dan Indosiar dalam diskusi Merumuskan Pola Baru Jurnalisme TV di Era New Normal yang digelar Ikatan Jurnalis Televisi Indonesia mengatakan bahwa perusahaannya memfasilitasi pekerja televisI baik di SCTV maupun Indosiar untuk bekerja dari rumah dalam masa COVID-19 ini. Koordinasi dan rapat kru juga dilakukan secara virtual. Presenter difasilitasi untuk siaran dari rumah tujuannya untuk di samping menjaga keselamatan presenter juga untuk memberi contoh kepada pemirsa tentang pentingnya untuk tetap berdiam di rumah. (IJTI, 2020)

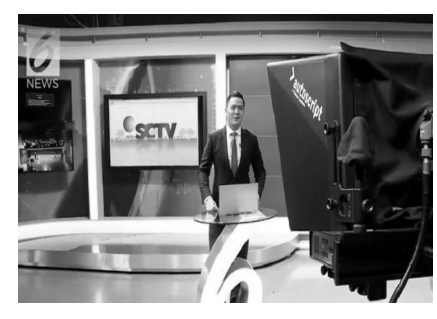

(a)

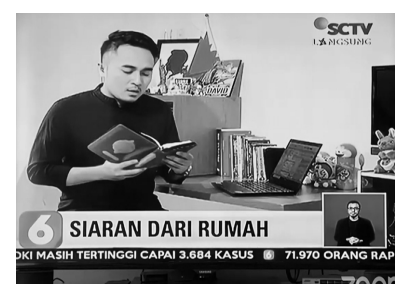

(b)

Gambar 2. (a) Presenter SCTV siaran di studio (b) Presenter SCTV siaran dari rumah (sumber (a) liputan6.com (b) Retno Pinasti, IJTI) 
Program siaran dari rumah yang lain misalnya reality show seperti The Onsu Family yang dibuat dengan format vlog dan juga Bikin Laper yang hanya dilakukan di apartement hostnya.(Humas UII, 2020). Kompas TV membuat kampanye mendukung kebijakan PSBB dengan membuat tagar \#TerhubungDariRumah. Dari sini banyak platform-nya seperti belanja dari rumah, jajan dari rumah, dan dapat menghubungkan antar kerabat dan keluarga. Kompas TV juga menggelar konser amal dari rumah bersama Didi Kempot dalam rangka mengumpulkan dana kemanusiaan untuk menangani COVID-19. Konser itu sendiri berhasil mengumpulkan dana 5,3 miliar dan dipuji Presiden Jokowi.(Aditia, Andika, 2020a)

Saat hari Raya Idul Fitri, KompasTV bersama Dompet Dhuafa menggelar konser kemanusiaan bertajuk "Konser Raya Dari Rumah \#LebaranDariRumah." Bersama Dwiki Dharmawan \& Friends menghadir Ita Purnamasari, Reza Artamevia, Radja, Indra Perdana Sinaga, Nola B3 \& Naura, Mario Ginanjar, hingga Anisa Rahman.(Aditia, Andika, 2020b)

\section{Program Belajar dari Rumah TVRI}

Dalam rangka mengoptimalkan program belajar dari rumah karena aktivitas lembaga yang terhent, Kementerian Pendidikan dan Kebudayaan bekerjasama dengan Televisi Republik Indonesia (TVRI) sebagai Lembaga Penyiaran Publik membuat program belajar dari rumah. Kerjasama ini dilakukan untuk membantu masyarakat yang tidak punya akses internet karena kondisi ekonomi maupun wilayah yang jauh dari jaringan sehingga tetap bisa mengiktui kegiatan belajar di rumah.

Pelaksana Harian Direktur Program dan Berita TVRI Usrin Usman mengatakan ini dimulai pada Senin 13 Maret 2020 pada pukul 8 pagi hingga 23.00 dengan diselingi program-program TVRI. Selain diisi oleh dengan program pembelajaran untuk semua tingkat satuan pendidikan, belajar dari rumah juga akan menyajikan program bimbingan orangtua dan guru serta tayangan kebudayaan pada akhir pekan.

Konten pembelajaran yang disajikan fokus pada peningkatan literasi, numerasi, penumbuhan karakter dan kecakapan hidup peserta didik yang disampaikan secara ringan dan menghibur. Kemendikbud, tambahnya, juga akan memantau dan mengevaluasi mengenai program ini bersama dengan lembaga non-pemerintah. Adapun jadwal pada jam 08-8.30 adalah materi PAUD, kemudian 8.30-9.00 untuk kelas I sampai kelas III SD, pukul 10.00-10.30 untuk kelas 4 dan kelas 6. Jam 10.30-11.00 untuk SMP, Kemudian 14.00-14.30 SMA, 14.30-15.00 pengasuhan dan pendidikan anak untuk orang tua dan guru.(Wardah, Fathiyah, 2020)

\section{TV Pool dan Kolaborasi}

Sebelum pandemi COVID-19 perusahaan media seperti televisi Indonesia jarang melakukan kolaborasi atau menggelar siaran bersama. Statisun televisi kebanyakan memproduksi siaran sendiri (in house production) baik siaran tapping atau news maupun siaran langsung. Namun sejak masa COVID-19 perusahaan televisi diminta untuk melakukan siaran bersama atau TV Pool dan Radio Pool. Salah satu TV Pool dalam masa COVID-19 adalah konferensi pers Gugus Tugas Percepatan Penanganan COVID-19 di Media Center BNPB Jakarta. Dalam konferensi pers yang biasanya 
dipandu Juru Bicara Pemerintah Ahmad Yurianto ini disiarkan secara langsung melalui TV Pool dan Radio Pool dengan hak siar boleh dipakai oleh semua media (Wibowo, Agus, 2020).

Dalam catatan Komite Keselamatan Jurnalis (KKJ) saat ini telah tersedia TV pool yang dilaksanakan oleh beberapa stasiun televisi di Balai Kota Jakarta, Istana Kepresidenan, Wisma Atlet, dan Badan Nasional Penanggulangan Bencana (BNPB) yang dapat dimanfaatkan untuk memenuhi kebutuhan video di semua media.(KKJ, 2020). Ketua IJTI Yadi Hendriana menegaskan hal tersebut tidak membuat berita di televisi menjadi sama. Sebab, masing-masing televisi cara memberitakan dari sudut pandang yang berbeda. "Ada perubahan di gathering. Misalkan di lapangan, Satellite News Gathering (SNG) yang dimiliki MNC ada di Istana, TVRI dan CNN di BNPB dan TV One di Balaikota. Begitu juga dengan Kompas dan Metro TV," jelas Yadi.(Madrim, Sasmito, 2020)

Dampak lain karena COVID-19 ini adalah munnculnya kolaborasi antarmedia termasuk televisi. Sebanyak 50 perusahaan media nasional dan lokal yang terdiri dari media cetak, siber, televisi dan radio berkolaborasi melawan Covid-19 dengan membuat wadah \#MediaLawanCovid19 Maret 2020 lalu. Wadah ini terbentuk sebagai respons penyebaran Covid-19 yang makin marak di Indonesia. Wadah ini memungkinkan antar perusahaan media yang tergabung dalam \#MediaLawanCovid19 untuk mendapatkan pengetahuan tentang keselamatan kerja di tengah wabah virus corona dan membuat kampanye yang edukatif bagi masyarakat penikmat media. Perusahaan media juga dapat berkolaborasi dalam membuat konten dan dipakai secara bersama-sama di tengah keterbatasan sumber daya manusia.(Damhuri, Elba, 2020).

Di antara kampanye yang dilakukan untuk menekan penyebaran COVID-19 adalah \#JanganMudik di samping menggunakan tagar \#AmanDiRumah. Kampanye dipublikasikan secara serentak selama dua hari di semua platform media mulai jaringan televisi, radio, majalah, koran, media siber maupun media sosial.(Defianti, Ika, 2020)

\section{Pola Kerja dan Protokol Kesehatan}

Retno Pinasti dari Surya Citra Media (IJTI, 2020) mengatakan pihaknya menerapkan protokol khusus terkait COVID-19 sejak Maret 2020. Upaya antisipasi yang dilakukan antara lain membagi dua tim terpisah yang masuk tiga hari gathering atau liputan dan produksi. Lokasi dua tim juga dipisah. Kalau biasanya jadi satu di SCTV Tower sekarang dipisah production di SCTV Tower, gathering di Kebon Jeruk. Konsekwensi ini jam kerja diperpanjang 9 jam jadi 12 jam. Juga ada tim bekerja dari rumah.

Retno juga memaparkan bahwa pihaknya menyiapkan fasilitas untuk mengantisipasi wabah ini yakni kamar mandi, diisfektan kantor 2 kali sehari, disinfektan alat dan mobil, liputan, mempersiapkan pengukur suhu, cuci tangan.Di samping itu juga dipersiapkan perlengkapan tim; masker, googles, faceshield, sarung tangan, handsanitizer, alas duduk, perlengkapan mandi, jas hujan. SCM juga mempersiapkann vitamin c intravena serta rapid test secara gratis bagi karyawannya. Juga ada allowance khusus makan siang bagi karyawan bawa dari rumah atau disediakan di kantor. 


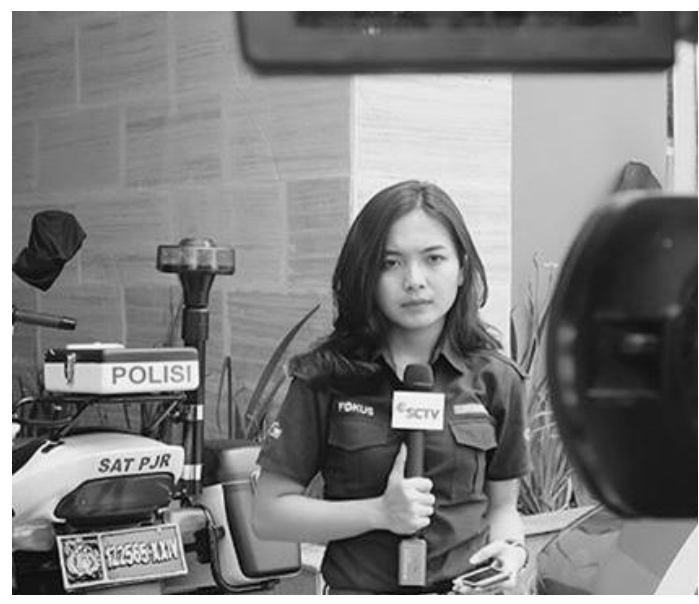

(a)

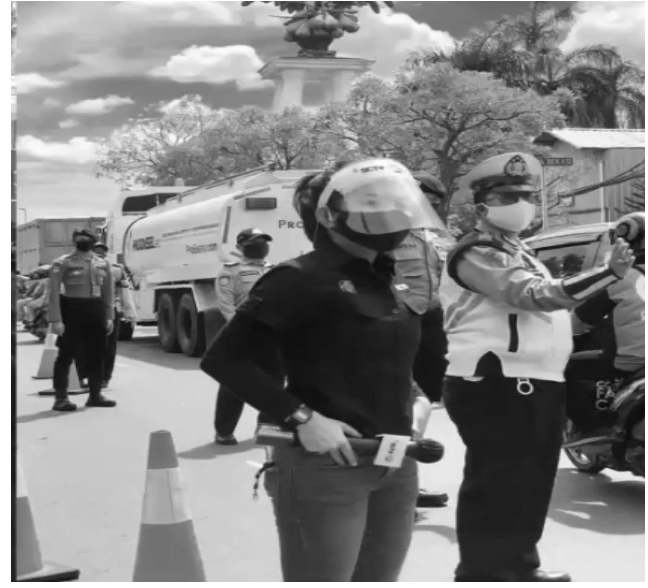

(b)

Gambar 3. (a) Reporter SCTV liputan lapangan sebelum COVID-19 (b) Reporter SCTV liputan di masa COVID-19 (sumber (a) liputan6.com, (b) Retno Pinasti, IJTI)

SCM juga membentuk satuan tugas supervisor aktif yang memantau ke seluruh tim (stress, rapid tes). Tim gathering atau lapangan fokus pada 3 aspek fasilitas, fafety, dan bekerja dari rumah. Penugasan tim liputan hanya di tempat yang krusial dan aman. Jika sudah ada sumber berita seperti tv pool atau live streaming tidak perlu mengirimkan tim. Wawancara dilakukan dengan menggunakan bom mic untuk menjaga jarak dengan narasumber. Di samping itu wawancara virtual atau mengirim pertanyaan kepada narasumber lalu dijawab dengan video.

Toto Suryanto, Wakil Pemimpin Redaksi TV One dampak yang dirasakan akibat COVID-19 selain sektor pendapatan, pola kerja juga berubah. Pihaknya lebih memerhatikan kebersihan dan keselataman kru yang bekerja. Toto mengaku langkah pencegahan telah dilakukan antara lain dengan mewajibkan penyemprotan disinfektan terhadap kendaraan operasional dan peralatan liputan secara berkala, serta pembagian shift kerja yang ketat. Selain penyiapan alat perlindungan diri yang memadai, menurutnya perlu ada protokol untuk menjaga gizi dan imunitas wartawan saat bertugas melakukan peliputan di lapangan. Pengaturan kerja di TV One menurut Toto berlaku berlaku tiga hari masuk dua hari libur. Pihaknya membagi shift kerja dalam dua kelompok. Dampaknya berkurang tenaga yang ke lapangan. Jika ada 20 puluh orang maka separuhnya yang ke lapangan. Adapun kontributor tetap berjalan karena mereka tidak berlaku work from home. (Litha, Yoanes, 2020).

TV One juga membuat aturan bagaimana kalangan internal dapat menjaga diri dan keluarganya. Keluarga pun harus menjaga bagaimana keluarganya tidak tertular. Di studio juga dituliskan siaran di studio harus jaga jarak karena kalau siaran jarang pakai masker sehingga jadi contoh bagi pemirsanya Di luar itu ada SOP jaminan terhadap tim lapangan apabila mereka tertular. Toto menilai siaran di tv sudah mulai membosankan. Gambar monoton. Ancaman orang tidak menonton tv semakin besar. "Misalnya bikin human interest akibat covid agak sulit dilakukan karena kita juga harus menjaga 
wartawan dan narasumber juga kadang menolak untuk ditemui". Toto juga mengatakan di samping penyemprotan disinfektan secara berkala dan memerhatikan kesehatan wartawan, pihaknya juga memerhatikan soal kebersihan tolilet, karena toilet selama ini menjadi tempat penyebaran virus.(IJTI, 2020)

Titin Rosmasari, Pemimpin Redaksi CNN Indonesia TV dan Trans 7 menilai ancaman virus corona membuat media harus beradaptasi, termasuk penggunaan teknologi informasi untuk mendapatkan materi berita maupun koordinasi di lingkungan tempat kerja. "Jurnalis reporting dari ruang kerjanya dari kamarnya dan dari depan rumahnya, virtual press conference online, bahkan kita sudah mulai melakukan virtual product launching kerjasama dan mulai ada beberapa client mau bekerjasama dengan kita," jelas Titin Rosmasari.(Litha, Yoanes, 2020).

Titin mengaku hingga Juli 2020 pihaknya belum akan mengirim wartawan dalam jumlah banyak terutama untuk melakukan peliputan sejumlah mata acara di luar ruangan atau di alam terbuka, termasuk membatasi mengundang narasumber ke studio untuk wawancara. "Kita tidak mau menjadikan jurnalis kita sebagai objek berita atau masuk dalam statistik karena ada penambahan COVID karena ada dari kru kita," tegas Titin.(IJTI, 2020)

Diakui Titin, jurnalis jenuh dengan WFH karena membuat ide dan ruang gerak terganggu, ditambah lagi harus ada yang isolasi diri. Jurnalis juga harus turun ke lapangan karena di lapangan dapat gesturenya, tahu orang berbohong, dan dapat ide baru untuk mengembangkan pertanyaan. "Jika wawancara melalui internet masalahnya ada di kuota, jaringan tidak baik, kadang kita mau gali pertanyaan kita hanya one way. Ada problem di situ. Old Normal ada liputan via virtual, "New normal untung ada teknologi ada menteri, TNI yang bisa bikin dibuat video conference meskipun ada yang beberapa dengan kualitas kurang baik. Kita meski mengikuti kita mesti adjust ada situasi ekonomi yang harus diselamatkan. Karena ada satu musuh yang tidak kelihatan." (IJTI, 2020)

Saat ini pihak Transmedia menurut Titin sedang disiapkan cubical antar ruang untuk jaga jarak. Satu ruang khusus untuk teman-teman yang dari lapangan. "Kita siapakan ruang untuk menyimpan baju di ruang. Sehingga bisa banyak yang lebih produktif di kantor. Spesialisasi saat ini dikembangkan kami butuh orang yang memahami liputan soal kesehatan, science journalism akan kita kembangkan. Kita akan sangat membutuhkan skill yang bisa menganalisa untuk kita ada basic jurnalis dari medis." Transmedia juga menyiapkan panduan liputan ke luar kota, luar negeri dan lainlain untuk menghindari pandemi ini.. Titin menilai perlu model bisnis baru untuk media. Karena banyak yang ofline harus berubah menjadi online. Isu kejenuhan orang akan berita covid. Orang gak mau tahu, tapi mereka abai. Ini menjadi tugas media untuk mengedukasi. Media harus kolaborasi dengan pemerintah, hanya saja kadang kita diminta untuk memberitakan dari versi pemerintah. (IJTI, 2020)

\section{Kesimpulan}

Wabah COVID-19 yang menyebar di Indonesia telah membawa dampak kepada industri siaran televisi. Dari hasil kajian diketahui bahwa terjadi beberapa perubahan dalam industri siaran antara lain karena larangan mengumpulkan banyak orang dalam jumlah besar maka beberapa televisi dan mitranya seperti rumah produksi 
menghentikan syuting untuk sementara waktu, membuat program siaran langsung tanpa penonton, menyiasati kekurangan program dengan tayang ulang konten yang lama atau re run. Cara melakukan tayang ulang ini juga disikapi berbeda oleh media televisi. Ada yang mengulang kembali tayangan secara utuh, ada juga yang menggabungkan beberapa adegan kompilasi dan mengemasnya ulang dalam episode special untuk mengisi kekosongan episode baru, seperti yang terjadi pada sinetron Dunia Terbalik.

Untuk keselamatan dan memberi contoh yang baik kepada warga untuk tetap tinggal di rumah stasiun televisi menggelar siaran dari rumah, untuk membantu pelajar yang jauh dari jaringan internet dan keterbatasan kuota, TVRI selaku Lembaga Penyiaran Publik membuat program belajar dari rumah. Untuk menghindari kerumunan wartawan dalam meliput perkembangan COVID-19 pemerintah menerapkan TV POLL atau siaran bersama di Badan Nasional Penanggulangan Bencana. Beberapa TV dan media lain juga berkolaborasi dalam melawan COVID-19. Stasiun televisi juga mengubah pola kerjanya dengan membagi dua tim ada yang bekerja di kantor ada yang di rumah, mereka membuat protokol kesehatan dan memantau kesehatan para kru televisi secara intens, sesuatu yang belum pernah terjadi sebelum wabah ini menyebar di Indonesia.

Dari hasil penelitian ini ditemukan fakta bahwa industri siaran televisi di Indonesia masih berupaya untuk bertahan dari terpaan badai COVID-19 atau sekedar mengisi kekosongan siaran semata, belum berupaya untuk keluar berkompetisi. Dengan kompetisi yang akan semakin ketat di masa depan perlu pemikiran serius untuk membuat stasiun televisi bertahan dan meningkatkan kualitas program di mata masyarakat.

\section{DAFTAR PUSTAKA}

Aditia, Andika. (2020a). Didi Kempot Konser Amal dari Rumah, Kumpulkan Rp 5,3 Miliar dan Dipuji Jokowi Halaman all. KOMPAS.com. https://www.kompas.com/hype/read/2020/04/12/072800866/didi-kempot-konseramal-dari-rumah-kumpulkan-rp-53-miliar-dan-dipuji-jokowi

Aditia, Andika. (2020b). Saksikan Malam Ini, Konser Raya Dari Rumah di KompasTV. KOMPAS.com.

https://www.kompas.com/hype/read/2020/05/22/183946666/saksikan-malam-inikonser-raya-dari-rumah-di-kompastv

AFP News Agency. (2020). How a Senegal TV series is fighting coronavirus. https://www.aljazeera.com/news/2020/05/senegal-tv-series-fighting-coronavirus200522160752049.html

Albarran, Alan. B. (2010). The Media Economy. Routledge.

Andueza-López, B., \& López-Plaza, M. (2020). The TV-Production Shift During the COVID-19 Health Crisis: How TV Language Changed As a State of Alarm Was Enforced in Spain. Trípodos, 2(47), 161-172-172.

Ball-Rokeach, S. J., \& DeFleur, M. L. (1976). A dependency model of mass-media effects. Communication Research, 3(1), 3-21. https://doi.org/10.1177/009365027600300101 
BBC News. (2020). Menkes terbitkan pedoman pelaksanaan PSBB, apa bedanya dengan pembatasan yang sudah terjadi? BBC News Indonesia. https://www.bbc.com/indonesia/indonesia-52104232

Bernie, M. (2020). Survei Cyrus Network: Penonton Mata Najwa Lampaui ILC TVOne. tirto.id. https://tirto.id/survei-cyrus-network-penonton-mata-najwa-lampaui-ilctvone-eEPz

Bisnis, H. M. (2020). Kemdikbud Imbau Stasiun TV Setop Syuting untuk Cegah Corona. MedanBisnisDaily.com.

https://medanbisnisdaily.com:443/news/online/read/2020/03/25/104000/kemdikbu d_imbau_stasiun_tv_setop_syuting_untuk_cegah_coronal

Business, B. S., CNN. (2020). Broadcasters adapt to social distancing and the new realities of covering a pandemic. https://www.cnn.com/2020/03/24/media/media-adjustments-coronaviruspandemic/index.html

Butts, Tom. (2020). 'What Day is It?': Comcast Sees New TV Watching Behaviors During Pandemic. TVTechnology. https://www.tvtechnology.com/news/what-dayis-it-comcast-sees-new-tv-watching-behaviors-during-pandemic

CNN Indonesia. (2020). Jokowi Imbau Masyarakat Bekerja dan Beribadah di Rumah. nasional. https://www.cnnindonesia.com/nasional/20200315141316-32483586/jokowi-imbau-masyarakat-bekerja-dan-beribadah-di-rumah

COVID-19 and TV. (2020). Thinkbox. https://www.thinkbox.tv/news-andopinion/opinion/covid-19-and-tv

Culinary. (2020). Library Research Methods: Library Research Basics. The Culinary Institute of America. https://library.culinary.edu/research/steps

Damhuri, Elba. (2020). Media Lawan Covid-19. Republika Online. https://republika.co.id/share/q7ozod440

Defianti, Ika. (2020). Cegah Penyebaran Corona, Media Lawan Covid-19 Serukan Jangan Mudik. liputan6.com. https://www.liputan6.com/news/read/4213883/cegah-penyebaran-corona-medialawan-covid-19-serukan-jangan-mudik

developer, medcom id. (2020, March 30). Dilema Rumah Produksi Film Diteror Korona. medcom.id. https://www.medcom.id/hiburan/montase//KYxEXxk-dilema-rumahproduksi-film-diteror-korona

Evandio, Akbar. (2020). Asosiasi Televisi Swasta Pahami Imbauan Kominfo | Teknologi. Bisnis.Com. https://teknologi.bisnis.com/read/20200408/84/1224637/asosiasitelevisi-swasta-pahami-imbauan-kominfo

Gomery, D. (2001). Television: Industry. In N. J. Smelser \& P. B. Baltes (Eds.), International Encyclopedia of the Social \& Behavioral Sciences (pp. 1558315586). Pergamon. https://doi.org/10.1016/B0-08-043076-7/04387-4

Gosip Artis. (2020). OVJ Syuting Tanpa Penonton, Denny Cagur: Ngeri Banget. kumparan. https://kumparan.com/gosip-artis/ovj-syuting-tanpa-penonton-dennycagur-ngeri-banget-1t3pMvjsLec

Hall, Stefan, \& Li, Cathy. (2020). What COVID-19 reveals about the value of media globally. World Economic https://www.weforum.org/agenda/2020/04/covid-19-media-value/ 
Hidayatullah, T. (2020). Penonton dan pengiklan di TV mulai beralih. Lokadata.ID. https://lokadata.id/artikel/penonton-dan-pengiklan-di-tv-mulai-beralih

Hodes, R. (2014). Broadcasting the pandemic: A history of HIV on South African television. HSRC Press.

Humas UII. (2020, May 23). Tantangan Industri Media di Kala Pandemi. Universitas Islam Indonesia. https://www.uii.ac.id/tantangan-industri-media-di-kala-pandemi/

Hutt, Rosamond. (2020). This is how the world's oldest broadcaster plans to keep culture alive during quarantine. World Economic Forum. https://www.weforum.org/agenda/2020/03/this-is-what-the-bbc-is-doing-for-ukaudiences-during-the-coronavirus-pandemic/

Ihsanuddin. (2020). Fakta Lengkap Kasus Pertama Virus Corona di Indonesia Halaman all. KOMPAS.com. https://nasional.kompas.com/read/2020/03/03/06314981/fakta-lengkap-kasuspertama-virus-corona-di-indonesia

IJTI. (2020). Merumuskan Pola Baru Jurnalisme TV di Era New Normal. https://www.youtube.com/watch?v=sfbEyECBR94

Johnson, D. (2020). Who Needs Original Programming? TV's Pandemic Strategies Bear Repeating. Forbes. https://www.forbes.com/sites/derekjohnson/2020/05/22/whoneeds-original-programming-tvs-pandemic-strategies-bear-repeating/

Kapanlagi. (2020). Bawakan Acara AKSI Indosiar Tanpa Penonton, Host Merasa Kesulitan.

KapanLagi.com.

https://www.kapanlagi.com/showbiz/selebriti/bawakan-acara-aksi-indosiar-tanpa-

penonton-host-merasa-kesulitan-b787f4.html

Kapanlagi.com. (2020). LIDA 2020 Digelar Tanpa Penonton di Studio, Reza Zakarya Tak Terlalu Rasakan Perbedaan Selama Jadi Juri. KapanLagi.com. https://www.kapanlagi.com/dangdut/lida-2020-digelar-tanpa-penonton-rezazakarya-tak-terlalu-rasakan-perbedaan-selama-jadi-juri-1a22fd.html

KKJ. (2020). Komite Keselamatan Jurnalis Kembali Serukan Pentingnya Jaga Jarak Aman untuk Pekerja Media. Aliansi Jurnalis Independen. https://aji.or.id/read/press-release/1047/komite-keselamatan-jurnalis-kembaliserukan-pentingnya-jaga-jarak-aman-untuk-pekerja-media.html

Komunikasi Unsoed. (2020). Media Televisi Bertahan Ditengah Pandemi-Webinar IImu Komunikasi Unsoed-31 Mei 2020. https://www.youtube.com/watch?v=FkWlhbRYwr0

Kurniasih, Anisa. (2020). Bagaimana Nasib Program Televisi Edisi Ramadan di Tengah Pandemi Corona? https://www.urbanasia.com/bagaimana-nasib-program-televisiedisi-ramadan-di-tengah-pandemi-corona-U11737

Litha, Yoanes. (2020). Pandemi Corona Ikut Pukul Industri Media. VOA Indonesia. https://www.voaindonesia.com/a/pandemi-corona-ikut-pukul-industrimedia/5442061.html

Lotz, Amanda D. (2007). "The Television Will Be Revolutionized". ,. New York University Press.

Low, Elaine, \& Otterson, Joe. (2020). Coronavirus Forces Broadcast TV Networks to Get Creative for Fall - Variety. https://variety.com/2020/tv/news/coronavirusbroadcast-tv-networks-series-1234612020/ 
Lubis, Mila. (2020). COVID-19 DAN DAMPAKNYA PADA TREN KONSUMSI MEDIA. https://www.nielsen.com/id/id/press-releases/2020/covid-19-dan-dampaknyapada-tren-konsumsi-media

Luhur, Puthut Ami. (2020). Media Televisi Masih Bisa Bertahan di Tengah Pandemi Covid-19-Suaramerdeka.com.

https://www.suaramerdeka.com/news/nasional/230735-media-televisi-masih-bisabertahan-di-tengah-pandemi-covid-19

Madrim, Sasmito. (2020). Komunitas Pers Pertanyakan Penerapan "Kelaziman Baru." VOA Indonesia. https://www.voaindonesia.com/a/komunitas-pers-pertanyakanpenerapan-kelaziman-baru-/5442789.html

MarkPlus. (2020). MarkPlus Industry Roundtable—Broadcast \& Media Industry LIVE. https://www.youtube.com/watch?v=Zk7q0k8zNgk\&t=21s

Media, K. C. (2020a). Cegah Covid-19, Komisi I Minta Televisi dan Radio Tak Kumpulkan Massa dalam Programnya Halaman all. KOMPAS.com. https://nasional.kompas.com/read/2020/03/16/07421801/cegah-covid-19-komisi-iminta-televisi-dan-radio-tak-kumpulkan-massa-dalam

Media, K. C. (2020b). Virus Corona Mewabah, SinemArt Setop Seluruh Kegiatan Syuting Sinetron. KOMPAS.com. https://www.kompas.com/hype/read/2020/03/26/080100966/virus-coronamewabah-sinemart-setop-seluruh-kegiatan-syuting-sinetron

Mosco, V. (2009). The Political Economy of Communication. SAGE Publications Ltd. https://doi.org/10.4135/9781446279946

Mustika, R. (2016). BUDAYA PENYIARAN TELEVISI DI INDONESIA. Masyarakat Telematika Dan Informasi : Jurnal Penelitian Teknologi Informasi dan Komunikasi, 3(1), 51-56. https://doi.org/10.17933/mti.v3i1.35

Nugraha, Bayu, \& Simbolon, Foe Peace. (2020, March 30). Wabah Corona, Kegiatan Syuting Film dan Sinetron Diimbau Dihentikan. https://www.vivanews.com/berita/metro/42993-wabah-corona-kegiatan-syutingfilm-dan-sinetron-diimbau-dihentikan

Pramudya, Windi Eka. (2020). Tanpa Penonton karena Covid-19, Program "Sahur Segerr" Tetap Tayang Live-Pikiran-Rakyat.com. https://www.pikiranrakyat.com/entertainment/pr-01370793/tanpa-penonton-karena-covid-19program-sahur-segerr-tetap-tayang-live

Priastuti, Clarissa Fauzany. (2020). Cegah Penyebaran Virus Corona, Mata Najwa Tayang Tanpa Penonton di Studio. Tribun Palu. https://palu.tribunnews.com/2020/03/18/cegah-penyebaran-virus-corona-matanajwa-tayang-tanpa-penonton-di-studio

Putra, Adi. (2020). Antisipasi Penyebaran Corona, 6 Program TV Ini Tayang Tanpa Penonton. IDN Times. https://www.idntimes.com/hype/entertainment/adiputra/antisipasi-penyebarancorona-6-program-tv-ini-tayang-tanpa-penonton

Rahmat. (2020). "Dunia Terbalik" Terkena Imbas Pandemi Covid-19, Terpaksa Melakukan Ini. dara.co.id. https://www.dara.co.id/dunia-terbalik-terkana-imbaspandemi-covid-19-terpaksa-melakukan-ini.html 
Rasdianto, Fajar Yusuf. (2020). Strategi siaran ulang demi pangkas beban operasional. https://www.alinea.id/. https://www.alinea.id/bisnis/strategi-siaran-ulang-demipangkas-beban-operasional-b1ZOD9vbf

Sihite, Ezra. (2020). Pertama Kali dalam Sejarah, Indonesia Lawyers Club Tak Ada Penonton. https://www.viva.co.id/berita/nasional/1205968-pertama-kali-dalamsejarah-indonesia-lawyers-club-tak-ada-penonton

UAF. (2018). Library Research Process | Elmer E. Rasmuson Library. The University of Alaska Fairbanks. https://library.uaf.edu/ls101-research-process

Wardah, Fathiyah. (2020). Belajar dari Rumah Lewat TVRI. VOA Indonesia. https://www.voaindonesia.com/a/belajar-dari-rumah-lewat-tvri/5368286.html

Warta Kota. (2020). Pagi Pagi Pasti Happy Tanpa Penonton, Uya Kuya: Minimalkan Penyebaran Virus Corona di Studio. Warta Kota. https://wartakota.tribunnews.com/2020/03/16/pagi-pagi-pasti-happy-tanpapenonton-uya-kuya-meminimalkan-penyebaran-virus-corona-di-studio

Wesscott, Tim. (2020). Impact of COVID-19 outbreak on channels and programmingOmdia. https://technology.informa.com/621591/impact-of-covid-19-outbreak-onchannels-and-programming

Wibowo, Agus. (2020). Perkembangan Penanganan COVID-19 | Gugus Tugas Percepatan Penanganan COVID-19. Covid19.Go.Id. https://covid19.go.id/agenda-detail/perkembangan-penanganan-covid-19-3

Yuwono, Hanang. (2020). Doa Bunga Zainal saat Terima Kenyataan Rumah Produksi Milik Suami Tutup Sementara karena Corona. Tribunnews.com. https://www.tribunnews.com/seleb/2020/03/26/doa-bunga-zainal-saat-terimakenyataan-rumah-produksi-milik-suami-tutup-sementara-karena-corona

Zubaidah, Hanum. (2020). Andy F Noya: Pertama Kali Siaran tanpa Penonton. https://mediaindonesia.com/read/detail/296667-andy-f-noya-pertama-kali-siarantanpa-penonton 